\title{
Productivity of Lettuce Under Organic Fertilization
}

\author{
José Júnior A. Sarmento ${ }^{1}$, Caciana C. Costa ${ }^{1}$, Maila V. Dantas ${ }^{1}$, Kilson P. Lopes ${ }^{1}$, Ivando C. de Macedo ${ }^{1}$, \\ Silva Marinês P. Bomfim ${ }^{1} \&$ José Wilson da S. Barbosa ${ }^{2}$ \\ ${ }^{1}$ Center for Agri-Food Science and Technology, Federal University of Campina Gande, Campina Grande, Paraíba, \\ Brazil \\ ${ }^{2}$ State Company of Technical Assistance and Rural Extension of Paraíba (EMATER-PB), Paraíba, Brazil \\ Correspondence: Caciana C. Costa, Center for Agri-Food Science and Technology, Federal University of Campina \\ Grande, in the Municipality of Pombal, Campina Grande, Paraíba, 58,840-000, Brazil. Tel: 55-83-3431-000. \\ E-mail: costacc@ccta.ufcg.edu.br
}

Received: September 20, 2018

Accepted: October 27, 2018 Online Published: December 15, 2018

doi:10.5539/jas.v11n1p335

URL: https://doi.org/10.5539/jas.v11n1p335

\begin{abstract}
Organic fertilizersare a viable alternative to reduce the expenses associated with synthetic fertilizers, besides improving the chemical, physical and biological attributes of the soil and promoting the increase of productivity in the cultivation of vegetables. The aim of this research was to evaluate the effect of goat manure applicatiosn on lettuce yield, cv. Cristina. The experiment was conducted at the Center for Agri-Food Science and Technology, Federal University of Campina Grande in the municipality of Pombal, PB, Brazil. The experiment was conducted in randomized blocks with treatments composed of five goat manure percentages $(0,25,50,75$ and $100 \%$ ), considering $100 \%$ of the recommended dose being 36.50 ton/ha de goat manure, in five replications, using a spacing of $0.25 \times 0.25 \mathrm{~m}$ between plants. Harvesting was performed 30 days after transplanting the seedlings. The following parameters were analyzed: aerial part height, plant diameter, number of leaves, aerial fresh weight, root fresh weight, total fresh weight, aerial dry weight, root dry weight, total dry weight, root volume and productivity. The data were submitted to polynomial regression analysis. When the lettuce plants cv. Cristina were fertilized with $75 \%$ of the $\mathrm{N}$ ratio required for maximum production, the goat manure application produced the greatest development and increase productivity.
\end{abstract}

Keywords: Lactuca sativa, nitrogen fertilization, manure

\section{Introduction}

The consumption of leafy vegetables, such as lettuce, is widely recommended, since these foods provide innumerable benefits to the body, such as organic development and regulation of the body, due to its high content of vitamins and minerals (Martins et al., 2008). The lettuce (Lactuca sativa L.), belonging to the Asteraceae family, stands out among the leafy vegetables, being the most consumed by the Brazilian population, besides being widely cultivated in all countries (Silva, Pinheiro, Paula, \& Prigol, 2015). In Brazil, its cultivation is traditionally carried out at family farms, a factor that adds value to the field and increasing the labor which has potential sociological benefits.

Due to the large demand for lettuce, it is important in improve the production practices that will increase its availability. Mineral fertilization, despite its advantages, brings with it significant negative environmental impacts, such as increasing soil salinity, decreasing long term fertility, decreasing organic matter, and the accumulation of agrochemicals in soils (Pedrotti et al., 2015).

Organic fertilization appears to be a good option for reducing mineral fertilizers expenditures, due to the greater availability of nutrients, especially nitrogen, phosphorus, sulfur and micronutrients, increasing the $\mathrm{pH}$, as well as the indirect benefits to the soil's physical, chemical and biological properties, and, thereby, increasing crop productivity (Kiehl et al., 1999; Santos et al., 1999; Santi et al., 2010).

Among the many sources of organic fertiliziers, we highlight the use of animal manure, the indirect effects that manure produce, due to its high organic matter content, and as a mean to improve a soil's physical, chemical and biological characteristics. In this context, goat manure is potentiallybeneficial because its lower carbon/nitrogen $(\mathrm{C} / \mathrm{N})$ ratio when compared to other manures (Souto et al., 2005). The lower $\mathrm{C} / \mathrm{N}$ ratio results in a higher 
mineralization speed of nutrients, an essential characteristic in the fertilization leafy vegetables, due to the rapid cycle of these crops.

The nutrient amounts excreted in the goat feces was evaluated by Orrico et al. (2007), where they obtained a dry matter mean of $1.39 \% \mathrm{~N} ; 0.62 \% \mathrm{P}$ and $0.29 \% \mathrm{~K}$, They also found an increase in nutrient concentrations in feces, as the animals approached the adult stage and were fed diets rich in concentrate.

Studies that provide information on the management of organic fertilization by the application of goat manure in the lettuce crop are extremely important for the construction of technical subsidies that aim at raising productivity rates, reducing fertilizer costs, and greater profitability to the producer. However, there are few studies that have investigated the application of goat manure in lettuce these are examples, Figueiredo et al. (2012); Batista et al. (2012); Peixoto Filho et al. (2013).

The use of this type of organic fertilizer is seen as a useful and economical practical for producers, especially vegetable producers, since it offers innumerable benefits, increasing fertility and soil conservation and thus providing organic nitrogen accumulation in the soil, increasing its potential of mineralization and its availability to plants. However, higher or lower application rates will depend on the soil type, texture, structure and organic matter content, since each manure type is unique characteristics and therefore must be studied in a singular way (Santos \& Trindade, 2010).

Thus, it is necessary to know the application rates of organic fertilizer that promotes the greatest crop production, because this factor directly relates with lettuce productivity indexes. Therefore, the objective of this work was to study the proportion of goat manure that will provide the maximum yield of lettuce, cv. Cristina.

\section{Material and Methods}

The researchwas conducted at the Center for Agri-Food Science and Technology, Federal University of Campina Grande, in the municipality of Pombal, Paraíba, Brazil from June 18 to August 18, 2016. The municipality climate, according to Koopen classification adapted to Brazil (Coelho \& Soncin, 1982), is of type BS h', which represents hot and dry climate with summer/fall rains, with an average precipitation of $750 \mathrm{~mL}$ by year. The experimental area soil was classified as Luvissolo Crômico Órtico typical (MAPA, 1972; Santos et al., 2013).

\subsection{Production of Lettuce Seedlings}

The lettuce seedlings cv. Cristina were produced in 200-cell expanded polystyrene trays, filled with commercial Hortplant ${ }^{\circledR}$ substrate, and allocated two seeds per cell. Ten days after emergence thye seedlings were thinned to one plant per cell. The seedlings were transplanted to the field beds on July 18, 2016, 30 days after sowing, when the majority seedlings had four leaves.

\subsection{Treatments and Experimental Design}

The experiment was a randomized complete block design and five goat manure treatments $(0,25,50,75$ and $100 \%$ ), which were determined by the nitrogen $(\mathrm{N})$ recommendation for the crop. Prior to incorporating the manure, dry samples of the material were collected to determinethe chemical attributes according to the methodology of (Donagema et al., 2011). The analyzes were done at the Laboratory of Analyzes of Soil, Water and Plants of the Federal Institute of Paraíba-Campus Sousa (Table 1).

Table 1. Chemical characterization of goat manure used in lettuce fertilization. Pombal, UFCG/CCTA 2016

\begin{tabular}{|c|c|c|c|c|c|}
\hline Sample & pH & Dry matter & $\mathbf{N}$ & $\mathbf{P}$ & $\mathbf{K}$ \\
\hline & & -------- \% --------- & 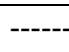 & $-----g$ & - \\
\hline Goat manure & 7.7 & 93.73 & 9.5 & 1.68 & 3.66 \\
\hline
\end{tabular}

After the determination of the nitrogenin the goat manure sample (Table 1), five ratios of goat manure $(0,25,50$, 75 and $100 \%$ ) were determined based on the fertilization recommendation of Raij et al. (1997), with $100 \%$ (36.50 ton/ha) as the manure dose calculated based on the goat manure nitrogen content and the amount of $\mathrm{N}$ required for the crop.

\subsection{Installation and Conduction of the Experiment}

The experimental area was cleared and all undesirable materials were removed prior to cultivation The soil was then plowed whith plow of large discor, to depth of $20 \mathrm{~cm}$ using and the beds were raised, $0.30 \mathrm{~m}$ high. Each experimental plot was $1.2 \mathrm{~m}$ long by $1.2 \mathrm{~m}$ wide, resulting in $1.44 \mathrm{~m}^{2}$ per plot. 
The pre-established proportions of the goat manure treatments, in $\mathrm{kg} / \mathrm{ha}$, were distributed and incorporated into the $0-15 \mathrm{~cm}$ layer of the plot using, applying $40 \%$ of the total recommended manure 15 days before transplanting and $60 \%$ of the recommended dose one day before transplanting the lettuce seedlings. The amount of goat manure was calculated according to Furtini Neto, Vale, Resende, Guilherme, and Guedes (2001), using the following expression:

Where,

$$
\mathrm{X}=\frac{\mathrm{A}}{\frac{\mathrm{B}}{\mathrm{B}} \cdot \frac{\mathrm{C}}{100} \cdot \frac{\mathrm{D}}{100}}
$$

$\mathrm{X}=$ amount of organic fertilizer to be applied, $\mathrm{kg} / \mathrm{ha} ; \mathrm{A}=$ dose of $\mathrm{N}$ required by the crop for a given yield, $\mathrm{kg} / \mathrm{ha}$ (Raij, Cantarella, Quaggio, \& Furlani, 1997); B = dry matter content of organic fertilizer, \%; $\mathrm{C}=\mathrm{N}$ content in dry matter of organic fertilizer, $\% ; \mathrm{D}=$ conversion index of $\mathrm{N}$ from the organic form to the mineral form, $50 \%$ (Furtini Neto et al., 2001).

The weeds were manually harvested from the emergence of weeds in order to avoid competition for water, light and nutrients. The irrigation system used in the area was of the micro sprinkler type with an emitter flow of 80 $\mathrm{mL} / \mathrm{h}$. Irrigation was done twice a day, with a duration of approximately $15 \mathrm{~min}$ each.

\subsection{Characteristics Evaluated}

The four center plants were used for data collection while the other plants were used as border plants. The day before the lettuce was harvested the plant heights and head diameters were measured, with values expressed in cm per plant.

On August 18, 30 days after transplanting, the lettuce plants, both the above gound plant and the roots, were harvested and then transported to the plant breeding laboratory of the Center for Agri-Food Science and Technology, Federal University of Campina Grande. The harvested plants were then washed and separated into the above ground plant material and the roots for evaluation. The number of leaves was obtained by counting all fully expanded leaves. The fresh weight of the aerial portion and the root were determined separately with the values expressed in grams per plant. The total fresh weight was the sum of the aerial portion and the roots expressed in grams per plant.

The separate plant portions were placed in paper bags for drying in a oven using forced air circulation at a $65{ }^{\circ} \mathrm{C}$ until a constant weight was obtained (determined by oven drying during $72 \mathrm{~h}$ and reweighing). The total plant dry weight is the sum of the dry weight of the aerial portion and roots expressed in grams per plant.

Root volume was determined by placing the fresh roots in a $1,000 \mathrm{~mL}$ beaker, containing a known volume of water $(500 \mathrm{~mL})$, by the difference, the direct root volume response was obtained by the equivalence of units (1 $\mathrm{mL}=1 \mathrm{~cm}^{3}$ ), according to the methodology described by Basso (1999).

Productivity was obtained by multiplying the total fresh mass of the lettuce by the population of plants extrapolated to $7,500 \mathrm{~m}^{2}$, considering the useful area of one hectare, expressed in ton/ha.

\subsection{Statistical Analysis}

The data were submitted to analysis of variance through the software SISVAR, version 5.6, according Ferreira (2011). The averages were adjusted in the linear and quadratic models through the simple polynomial regression analysis.

\section{Results and Discussion}

For aerial part height (Figure 1A), there is a positive response to the increasing use of goat manure doses, obtaining a higher performance of the variable when applied to the $100 \%$ dose (36.50 ton/ha of goat manure) resulting, according to the derivative of the equation, in a maximum average of $23.95 \mathrm{~cm}$ per plant, showing the significant effect of the availability of nutrients through manure. The various benefits of organic fertilization occur as a result of the release of nutrients as the organic waste is decomposed into the soil, thereby providing a higher production of plants.

Positive results in relation to the use of goat manure were found in experiments carried out with lettuce submitted to manure (bovine and goat) and nutrient concentration by Silva et al. (2011) goat manure provided greater efficiency in lettuce growth and yield. 

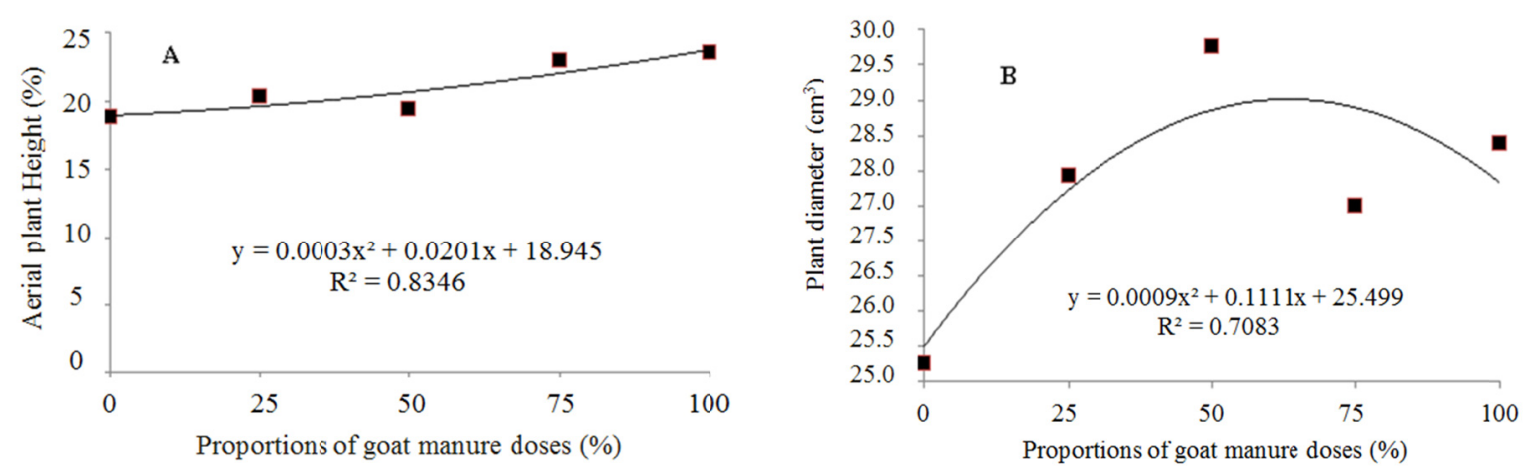

Figure 1. Aerial part height (A) and (B) plant diameter of the lettuce, according to different proportions of goat manure doses. Pombal, UFCG/CCTA 2016

For the plant diameter variable (Figure 1B), the best performance was observed in the amount of 22.50 ton/ha $(61.66 \%)$, whose observed value was $28.92 \mathrm{~cm}$. This behavior is associated with the amount of nutrients provided by the higher doses; where near the highest manure doses may have been sufficient for the development of the plants.

Nascimento et al. (2007) studied lettuce production with different bovine manure doses, found that the diameter of the plant tended to decrease with the increase of manure doses from the 12.5 ton/ha dose of bovine manure.

Figure 2A shows an increase in the average number of lettuce leaves as a function of the increase in goat manure up to 20.13 ton/ha (equivalent to the application of $73.55 \%$ of the recommendation), decreasing until the maximum amount incorporated in the soil. The doses provided promoted positive responses in the number of leaves produced by the lettuce, possibly providing the crop with greater nutritional availability and providing adequate conditions for a greater development of the plants. These results are similar to those found by Cruz et al. (2010), when they combined goat manure volume with hydrocorretent doses, and analyzed the effects of manure volumes in isolation, which confirmed that doses of 20 and $40 \%$ (volume in soil), caused the same behavior in the number of lettuce leaves.

For the root volume (Figure 2B), there is a growing increase between the lowest and the highest amount of goat manure applied to the soil. The dose of 27.38 ton/ha provided an environment conducive to further development of these, probably the greatest amount of nutrients and organic matter provided by that dose promoted favorable conditions for the roots to reach a larger volume through greater porosity, aeration and improvement in the other physical qualities of the soil, with this the roots obtained adequate conditions for greater exploitation of the nutrients available in the soil.
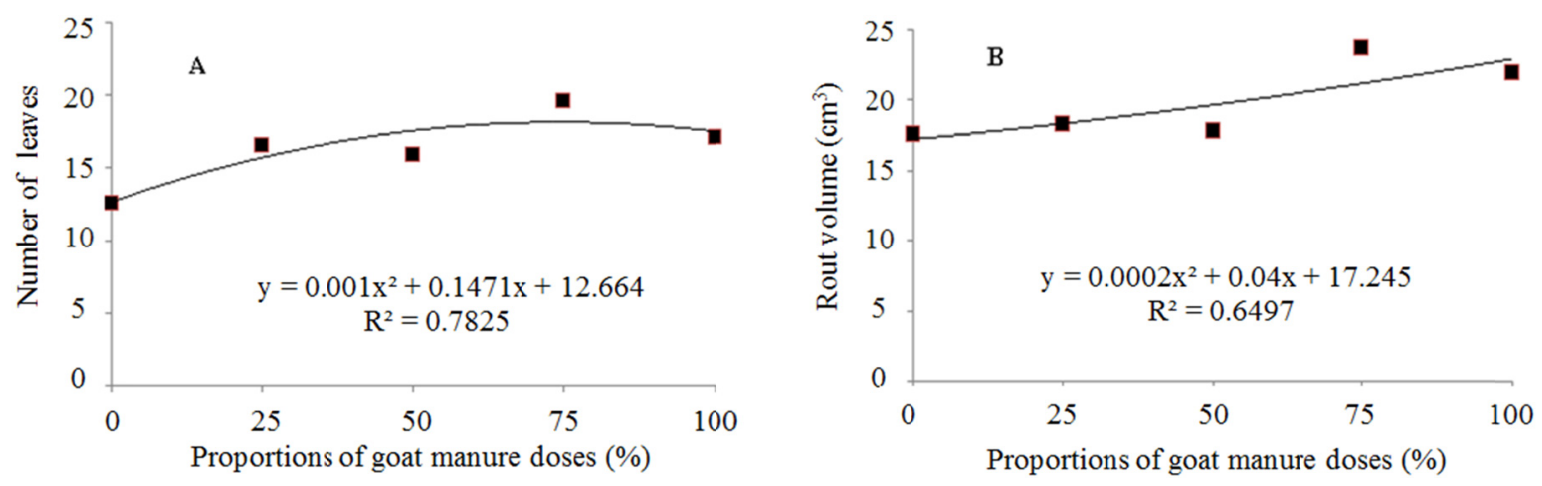

Figure 2. Number of leaves (A) and volume root (B) of the lettuce, according to different proportions of goat manure doses. Pombal, UFCG/CCTA 2016

Melo et al. (2015) believe that the benefits of goat manure on crop development and yield are due not only to the nutrient supply, but also to the improvement of other soil constituents, of water, in the aeration of its structure by means of formation of humus-clay complexes and, consequently, increase in the CTC, providing better 
utilization of the nutrients. In addition, the results obtained in this research with goat manure confirms Filgueira (2012) regarding the importance of organic fertilization, especially with manure, to this crop of delicate and demanding roots regarding the physical aspects of the soil.

It is verified that to the fresh mass of the aerial portion (MFPA) (Figure 3A) when applying the equation, generated by the polynomial regression graph, increasing doses provided a growing line, however the best average was presented in the dose referring to $75 \%$ of the recommendation $(27.38 \mathrm{ton} / \mathrm{ha})$, generating favorable conditions for its higher production. The values ranged from $332.8 \mathrm{~g}$ per plant $(0 \%$ dose) to $488.9 \mathrm{~g}$ per plant $(100 \%$ dose) with this finding that said dose made the macros and micronutrients needed more efficiently and in an amount adequate for improved soil structure, promoting greater water retention, higher CTC, and increased biological activity of the same, through the greater addition of organic matter, where organic materials as sources of macro and micronutrients and because they provide innumerable beneficial physical, chemical and biological properties of the soil, are widely recommended in the production of vegetables.
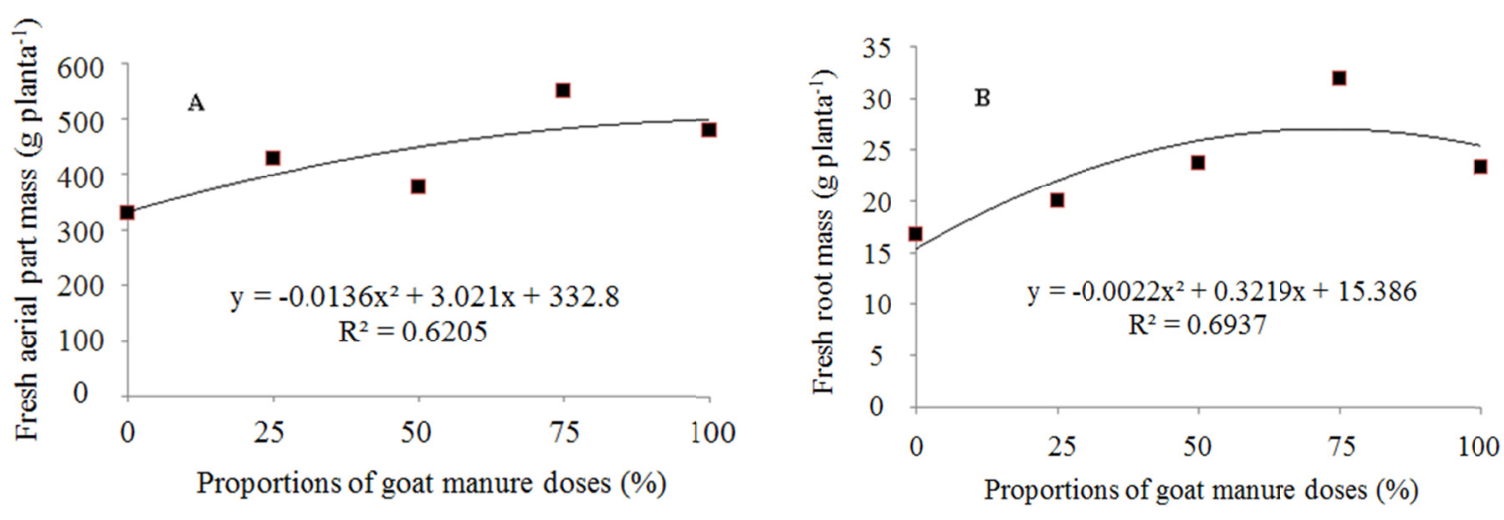

Figure 3. Fresh aerial part mass (A) and fresh root mass (B) of the lettuce, according to different proportions of goat manure doses. Pombal, UFCG/CCTA 2016

The decrease in production at higher doses may have occurred due to excess nitrogen $(\mathrm{N})$, a result of mineralization by the material. This behavior is similar to that found by Silva et al. (2010), when studying different compounds and application rates in lettuce production, they observed a linear increase of the MFPA production, but the best results were found in the doses 100\% (compounds 1 and 2) and at doses $75 \%$ (compounds 3 and 4), according to the analyzes of compounds 3 and 4, observed that the total $\mathrm{N}$ value in compound 3 is on average 1.6 times greater than in the others, promoting in higher dose excess $\mathrm{N}$ supply, resulting in reduced production.

For the total fresh weight (MFT) (Figure 4A), it was observed that the increment provided by the $75 \%$ concentration of the recommended dose $(27.38$ ton/ha) relative to the control $(0 \%$ dose $)$ was $40.32 \%$, reaching the maximum estimated value for MFT of $525.4 \mathrm{~g}$ per plant. It can also be observed that all the treatments that received manure exceed the one that did not receive the application, that is, the control $(0 \%)$, thus favoring the use of goat manure in lettuce fertilization. Rodrigues et al. (2008) obtained similar data for the fresh weight by studying the amounts of bovine manure in the arugula crop, and observed a tendency to increase both fresh and dry weight from 20 to of manure per hectare up to 60 ton of manure per hectare, from which a decrease in the production of freash weight begins to occur. 

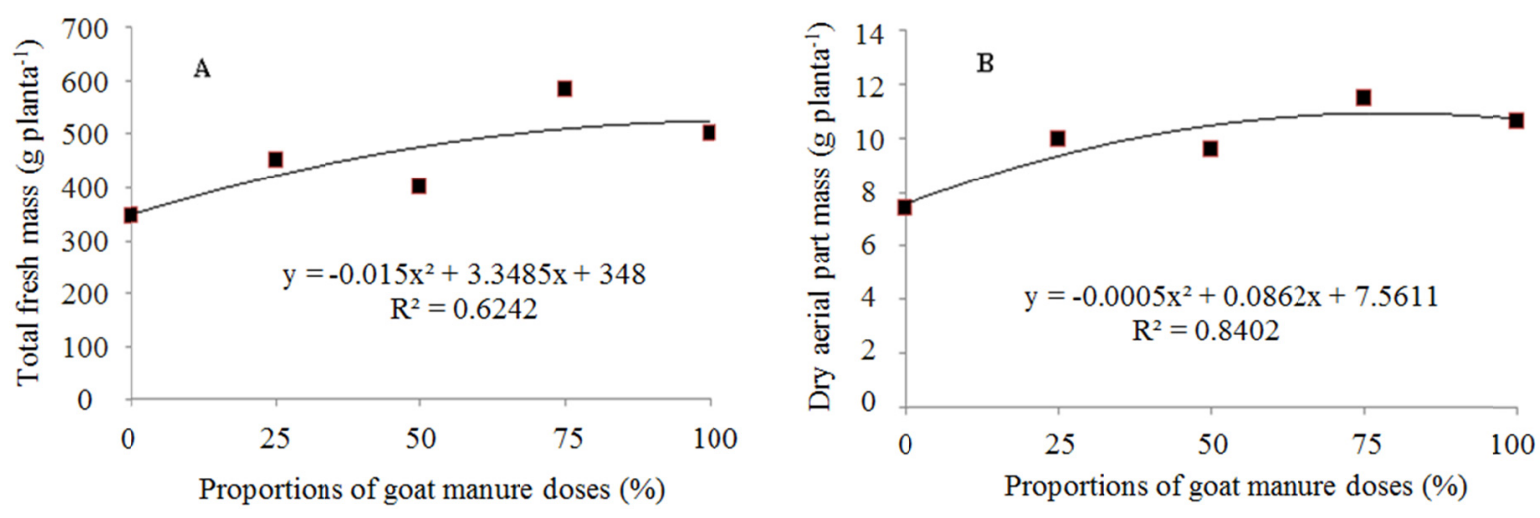

Figure 4. Total fresh mass (A) and dry mass of aerial part (B) of the lettuce, according to different proportions of goat manure doses. Pombal, UFCG/CCTA 2016

For the dry mass of the aerial portion (Figure 4B), it was observed that the proportion of $75 \%$ (27.38 ton/ha) presented the best results, providing a higher shoot dry weight production (11.21 g per plant), whereas the lowest result was obtained in the treatment without addition of manure ( $7.56 \mathrm{~g}$ per plant), a fact that may be associated to the greater increase of organic matter to the soil, providing greater nutrient demand to the plants, in addition to maintaining a good soil structure, with greater water retention and a nutrient replacement in the soil solution, maintaining the nutritional balance with the nutrient mineralization provided by the goat manure. These results are similar to those found by Silva et al. (2010) studying lettuce response to different doses of compounds showed that three of the four compounds studied presented better results for MSPA at a dose of $75 \%$ of the recommendation.

In figure $5 \mathrm{~A}$, it is again verified that the proportion of $75 \%$ stood out in relation to the others, providing the lettuce culture adequate conditions for a greater production of root dry weight. The higher dry matter acquisition is related to the water content present in the soil, as well as the greater availability of nutrients to the plants, this fact associated to the addition of organic matter in the soil, will retain a greater amount of water, and through its decomposition, will provide nutrients to the plants, resulting in improved soil structure, building their fertility and providing the roots of the lettuce suitable conditions for a greater production of dry mass through the greater exploitation of soil resources provided by the dose that is equivalent to $75 \%$ of the dose in its entirety.
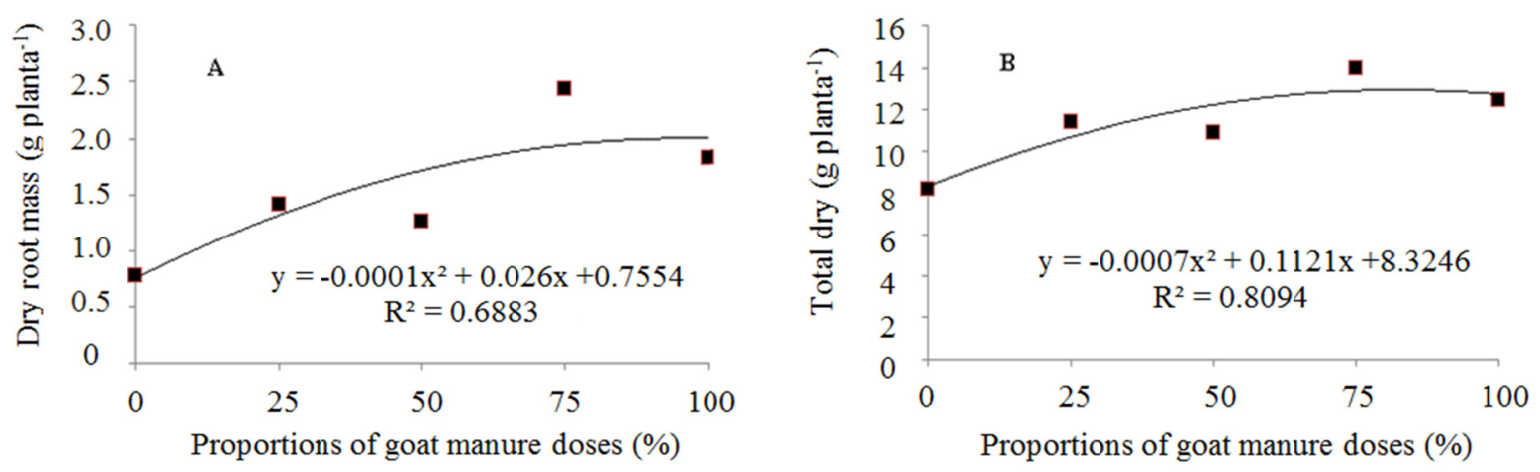

Figure 5. Dry root mass (A) and total dry mass (B) of the lettuce, depending on the different doses of goat manure. Pombal, UFCG/CCTA 2016

In the results of the total dry mass (Figure 5B), there is a constant growth as there is a higher amount of goat manure, with a drop after the proportion of $75 \%$ (27.38 ton/ha), thus providing a greater amount of organic matter to the soil, providing better physical, chemical and biological characteristics, thus increasing the macro and micronutrient contents, favoring adequate conditions for a greater production of the dry mass and a greater exploitation of the available nutrients. These results are consistent with those found by Rodrigues et al. (2008), which, by evaluating the performance of arugula as a function of the increasing dose of bovine manure, observed 
an increasing effect under the dry matter of the plants until the dose corresponding to $60 \%$ of bovine manure, point from which a fall begins to occur dry mass.

For the productivity (Figure 6), the highest average (7.12 ton/ha) was obtained in the proportion of $75 \%$ ( 27.38 ton/ha), giving an increase of $33.94 \%$, relative to the control. It can be seen that the proportions of 75 and $100 \%$ (27.38 and 36.50 ton/ha, respectively) lead, according to the equation of the graph, to equal production values (6.51 ton/ha). Similar results were observed by Mendonça \& Reis (2010), when studying lettuce yield under different doses of pig manure, that lettuce yield increased until the 40 ton/ha dose.

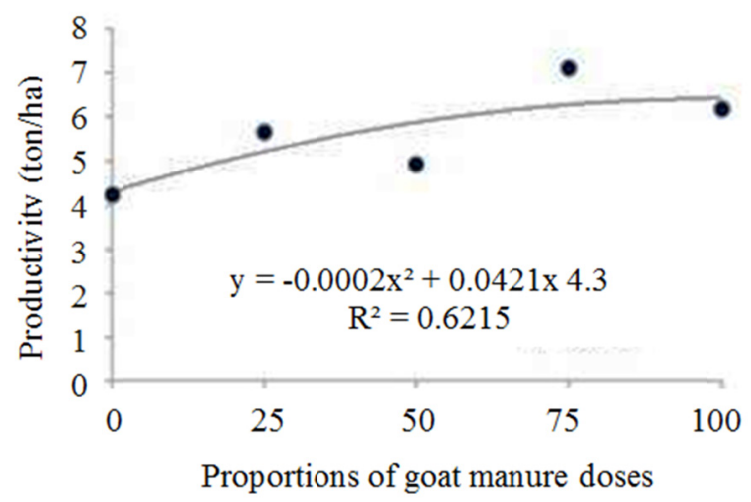

Figure 6. Productivity of the lettuce, according to different proportions of goat manure doses. Pombal, UFCG/CCTA 2016

\section{Conclusions}

The use of increasing proportions of goat manure promotes increases in developmental characteristics in relation to the control until the proportion of $75 \%$ of the $\mathrm{N}$ recommended dose (27.38 ton/ha of goat manure).

The fertilization with 27.38 ton/ha of goat manure provided higher efficiency, favoring a consequent increase in lettuce productivity.

\section{References}

Basso, S. M. S. (1999). Caracterização morfológica e fixação biológica de nitrogênio de espécies de Adesmia DC. e Lotus L. (Tese (Doutorado em Zootecnia), Universidade Federal do Rio Grande do Sul, Porto Alegre).

Batista, M. A. V., Vieira, L. A., Souza, J. P., Freitas, J. D. B. F., \& Bezerra Neto, F. (2012). Efeito de diferentes fontes de adubação sobre a produção de alface no município de Iguatu-CE. Revista Caatinga, 25(3), 8-11.

Coelho, M. A., \& Soncin, N. B. (1982). Geografia do Brasil (p. 368). São Paulo: Moderna.

Cruz, L. C., Santos, F., Brito, L. D. L., Pereira, L., \& Miguel, A. (2010). Efeito de diferentes doses de hidrorretentor e esterco de caprinos no desenvolvimento de alface crespa. J. De Iniciação Científica Da Embrapa Semiárido, 5, Petrolina. Anais... Petrolina: Embrapa Semiárido. Retrieved from https://www.alice. cnptia.embrapa.br/handle/doc/873228

Donagema, G. K., Campos, D. B., Calderano, S. B., Teixeira, W. G., \& Viana, J. M. (2011). Manual de Métodos de Análise de Solo (2nd ed., p. 230). Rio de Janeiro: Embrapa Solo.

Ferreira, D. F. (2011). Sisvar: A computer statistical analysis system. Ciência e Agrotecnologia, 35(6), 1039-1042. https://doi.org/10.1590/S1413-70542011000600001

Figueiredo, C. C. D., Ramos, M. L. G., Pimentel, C. M. M., \& Menezes, A. M. D. (2012). Mineralização de esterco de ovinos e sua influência na produção de alface. Revista Horticultura Brasileira, 30(1), 175-179. https://doi.org/10.1590/S0102-05362012000100029

Filgueira, F. A. R. (2012). Novo manual de olericultura: Agrotecnologia moderna na produção e comercialização de hortaliças (3rd ed., p. 412). Viçosa: Editora UFV.

Furtini Neto, A. E., Vale, F. R., Resende, Á. V., Guilherme, L. R. G., \& Guedes, G. A. A. (2001). Fertilidade do solo (p. 261). Lavras: UFLA/FAEPE, Minas Gerais. 
Kiehl, E. J. (1985). Fertilizantes Orgânicos (p. 492). São Paulo: Ceres.

MAPA (Ministério da Agricultura, Pecuária e Abastecimento). (1972). Levantamento Exploratório: Reconhecimento de Solos do Estado da Paraiba (p. 670). Rio de Janeiro: Equipe de Pedologia e Fertilidade do Solo.

Martins, A. C. A., Silva, L., Santos, J., Andrade, L., \& Martins, L. P. (2008). Avaliação da qualidade microbiológica da alface (Lactuca sativa) comercializada na cidade de Bananeiras-PB. Jornada Nacional Da Agroindústria, 3, Bananeiras, PB. Anais... Bananeiras: UFPB.

Melo, R. F., Anjos, J. B., Silva, A. F., Pereira, L. A., \& Cruz, L. C. (2015). Influência de doses de esterco de caprino no desenvolvimento de mandioca de mesa (Manihot esculenta Crantz) em barragem subterrânea. Congresso Brasileiro De Ciência Do Solo, 35, Natal. O solo e suas múltiplas funções. Anais... Natal: Sociedade Brasileira de Ciência do Solo.

Mendonça, R. M., \& Reis, J. M. G. C. (2010). Produção de alface sob diferentes doses de esterco suíno. FAZU em Revista, 7, 80-85.

Nascimento, I. L. S., Medeiros, D. C., Lopes, W. A. R., Góis, S. B., Tomaz, H. V. D. Q., \& Callegari, R. A. (2007). Produção de alface em função de diferentes dosagens de esterco bovino. $47^{\circ}$ Congresso Brasileiro De Olericultura, 25, Porto Seguro, BA. Anais... Porto Seguro-BA: Horticultura Brasileira.

Orrico, A. C. A., Lucas Jr., J., \& Orrico Jr., M. A. P. (2007). Caracterização e biodigestão anaeróbia dos dejetos de caprinos. Revista Engenharia Agrícola, 27(3), 639-647. https://doi.org/10.1590/S0100-69162007000 400006

Pedrotti, A., Chagas, R. M., Ramos, V. C., Prata, A. P. N., Lucas, A. A. T., \& Santos, P. B. (2015). Causas e consequências do processo de salinização dos solos. Revista Eletrônica em Gestão, Educação e Tecnologia Ambiental, 19(2), 1308-1324.

Peixoto Filho, J. U., Freire, M. B. D. S., Freire, F. J., Miranda, M. F., Pessoa, L. G., \& Kamimura, K. M. (2013). Produtividade de alface com doses de esterco de frango, bovino e ovino em cultivos sucessivos. Revista Brasileira de Engenharia Agrícola e Ambiental, 17(4), 419-424. https://doi.org/10.1590/S1415-43662 013000400010

Raij, B. V., Cantarella, H., Quaggio, J. A., \& Furlani, A. M. C. (1997). Recomendações da adubação e calagem para o Estado de São Paulo (Boletim Técnico, 100, 2nd ed., p. 285). Campinas: IAC.

Rodrigues, G. S. O., Torres, S. B., Linhares, P. C. F., Freitas, R. D. S., \& Maracajá, P. B. (2008). Quantidade de esterco bovino no desempenho agronômico da rúcula (Eruca sativa L.), cultivar cultivada. Revista Caatinga, 21(1), 162-168.

Santi, A., Carvalho, M. A., Campos, O. R., Silva, A. F., Almeida, J. L., \& Monteiro, S. (2010). Ação de material orgânico sobre a produção e características comerciais de cultivares de alface. Revista Horticultura Brasileira, 2(8), 87-90. https://doi.org/10.1590/S0102-05362010000100016

Santos, A. W., \& Trindade, A. M. G. (2010). Analise do crescimento e desenvolvimento de melancia submetida a diferentes doses de esterco caprino. Revista Agropecuária Técnica, 31(2), 170-173. https://doi.org/ 10.25066/agrotec.v31i2

Santos, H. G., Anjos, L. H. C., Oliveira, V. Á. V., Lumbreras, J. F., Coelho, M. R., Almeida, J. A., ... Oliveira, J. B. (2013). Sistema Brasileiro de Classificação de Solos (3rd ed., p. 353). Rio de Janeiro: Embrapa.

Santos, I. C., Casali, V. W. D., \& Miranda, G. V. (1999). Teores de metais pesados, K e Na, no substrato, em função de doses de composto orgânico de lixo urbano e de cultivares de alface. Revista Ciência Rural, 29. https://doi.org/10.1590/S0103-84781999000300006

Silva, E. M. N. C. P., Ferreira, R. L. F., Neto, S. E. D. A., Tavella, L. B., \& Solino, A. J. (2011). Qualidade de alface crespa cultivada em sistema orgânico, convencional e hidropônico. Revista Horticultura Brasileira, 29(2), 242-245. https://doi.org/10.1590/S0102-05362011000200019

Silva, F. A. M., Bôas, L. R., \& Silva, R. B. (2010). Resposta da alface à adubação nitrogenada com diferentes compostos orgânicos em dois ciclos sucessivos. Revista Acta Scientiarum, 32(1), 131-137. https://doi.org/ 10.4025/actasciagron.v32i1.1340

Silva, M. R. P., Pinheiro, F. C., De Paula, M. T., \& Prigol, M. (2015). Avaliação parasitológicas de alfaces (Lactuca sativa) comercializadas em municípios da fronteira Oeste, Rio grande do Sul, Brasil. Revista Patologia Tropical, 44(2),163-169. https://doi.org/10.5216/rpt.v44i2.36646 
Souto, P. C. Souto, J. S., Santos, R. V., Araújo, G. T., \& Souto, L. S. (2005). Decomposição de estercos dispostos em diferentes profundidades em área degradada no semiárido da Paraíba. Revista Brasileira Ciência do Solo, 29(1), 125-130. https://doi.org/10.1590/S0100-06832005000100014

\section{Copyrights}

Copyright for this article is retained by the author(s), with first publication rights granted to the journal.

This is an open-access article distributed under the terms and conditions of the Creative Commons Attribution license (http://creativecommons.org/licenses/by/4.0/). 